\title{
Effect of Toxic Heavy Metal Contaminated Soil on an Ornamental Plant Georgina wild (Dahlia)
}

\author{
Lovely Shivhare and Sunita Sharma*
}

Department of Biotechnology, Madhav Institute of Technology and Science, Gwalior, India

\begin{abstract}
Phytoremediation is an emerging technology for cleaning up contaminated sites, which is cost effective, and has aesthetic advantages and long term applicability. The report suggests about the mobility, bioavaliability and plant response to the presence of soil heavy metals. A greenhouse experiment was conducted to determine the phytotoxic effect of heavy metals such as $\mathrm{Ni}$ and $\mathrm{Pb}$ on the growth of Georgina wild. The selected metals were dosed at various concentration ranging from $0.5,1.0,1.5,2.0 \mathrm{mg} / \mathrm{kg}$ for nickel and $5.0,10,15,20 \mathrm{mg} / \mathrm{kg}$ for lead separately in soil. The results revealed that as the concentration of heavy metal in soil increases, the overall length of plant decreases with respect to control.
\end{abstract}

Keywords: Heavy metal; Ornamental plant; Phytoremediation; Georgina wild

\section{Introduction}

Soils contaminated with heavy metals cause many environmental and human health problems calling for an effective technological solution [1]. Many sites around the world remain contaminated because it is expensive to clean them up by available technologies [2]. There can be chemical and biological treatment of the same, the latter includes the microbial remediation and phytoremediation [3-5]. Phyto extraction may provide an attractive alternative for the clean up of heavy metal-contaminated soils. The goal of heavy metal phyto extraction is to reduce metal levels in the soil up to the acceptable levels with in a reasonable time frame [5].

Nickel, lead and mercury are the micronutrients essential for the soil. They occur naturally in the plant and animal tissue [6]. They are required in only very small amount, if plants are supplied these heavy metals more than they require, it will lead to toxicity in them and ultimately death. The usual routes by which human receive exposure to these heavy metals are through skin or eye contact, as well as inhalation of powders and dust.

In this study we choose Georgina wild (Dahlia) which is a popular ornamental plant for the Phytoremediation Nickel and Lead from the contaminated soil. Dahlia is a genus of bushy, tuberous, perennial plants native to Mexico. Nickel (Ni) is a nasty toxic metal and a known carcinogen. It is one of the metals we see most commonly in toxicity tests. Nickel can cause several unwanted effects, such as, higher chances of development of lung cancer, nose cancer, larynx cancer and prostate cancer, Sickness and dizziness after exposure to nickel gas, Lung embolism, Respiratory failure, Birth defects, Asthma and chronic bronchitis, Allergic reactions such as skin rashes, mainly from jewelry, Heart disorders. Lead poisoning (also known as plumbism, Colica pictonum, saturnism, Devon colic, or painter's colic) is a medical condition caused by increased levels of the heavy metal lead in the body. Lead interferes with a variety of body processes and is toxic to many organs and tissues including the heart, bones, intestines, kidneys and reproductive and nervous systems. It interferes with the development of the nervous system and is therefore particularly toxic to children, causing potentially permanent learning and behavior disorders. Symptoms include abdominal pain, confusion, headache, anemia, irritability, and in severe cases seizures, coma, and death.

\section{Materials and Methods}

\section{Soil collection}

Soil samples were collected from the farm site of MITS College Gwalior. The Soil samples were collected from surface, $10 \mathrm{~cm}$ and 20 $\mathrm{cm}$ depths by using soil sampler. Soil samples were air dried, sieved through $2 \mathrm{~mm}$ screens and thoroughly mixed before use. Physical and chemical property (i.e., soil texture, moisture content, soil $\mathrm{pH}$ ) were and analyzed.

The $\mathrm{pH}$ of the soil is an important factor in determining the growth of plant because soil $\mathrm{pH}$ controls which nutrients are available to plant for use. 20 grams of soil was weighed in a beaker and $40 \mathrm{ml}$ of distilled water was added with continuous stirring for 30 seconds in every 3 minutes for 15 minutes. After the final stir, the mixture was allowed to settle for 5 minutes and carefully the $\mathrm{pH}$ was recorded in the liquid phase.

Moisture content was determined by ratio of the weight of water in the soil to the weight of dry soil. The ratio was expressed as percentage, the percentage moisture contents was corrected by using moisture correction factor (MCF).

$$
\mathrm{MCF}=100+\% \text { Moisture } / 100
$$

100 grams of soil was weighed in the petriplate with water contents and after that the soil sample was dried in the hot air oven and after the proper drying the soil sample was weighed again and finally both values put in the formula and the moisture content of soil was calculated.

\section{Experimental pots preparation}

To initiate the experiment under controlled condition the soil was

*Corresponding author: Sunita Sharma, Department of Biotechnology, Madhav Institute of Technology and Science, Gwalior, 474005, India, E-mail: sunitasharma75@yahoo.co.in

Received July 31, 2012; Accepted September 26, 2012; Published October 01, 2012

Citation: Shivhare L, Sharma S (2012) Effect of Toxic Heavy Metal Contaminated Soil on an Ornamental Plant Georgina wild (Dahlia). J Environ Anal Toxicol 2:156. doi:10.4172/2161-0525.1000156

Copyright: (c) 2012 Shivhare L, et al. This is an open-access article distributed under the terms of the Creative Commons Attribution License, which permits unrestricted use, distribution, and reproduction in any medium, provided the original author and source are credited. 
air-dried, crushed, mixed thoroughly and passed through a $2 \mathrm{~mm}$ sieve About $1 \mathrm{~kg}$ of the soil placed into plastic pots $(25 \mathrm{~cm}$ in diameter and 14 $\mathrm{cm}$ in length) and then various concentration of Nickel $(0.5 \mathrm{mg}, 1.0 \mathrm{mg}$, $1.5 \mathrm{mg}, 2.0 \mathrm{mg}$ ) and Lead ( $5 \mathrm{mg}, 10 \mathrm{mg}, 15 \mathrm{mg}, 20 \mathrm{mg}$ ) was added in the experimental polythene bags and mixed it in soil by using hand gloves. Thus metals are properly mixed with the soil. Next day $10-15$ seeds of Dahlia were sown separately in each treated and control polythene bags. For each concentration of particular metal 5 pots are prepared. These polythene bags were properly and regularly irrigated.

\section{Plant harvest and analysis}

Plant samples were gently removed from the pots 45 days after sowing for the measurement of various growth parameters and biochemical analysis. Plants were harvested early in the morning between 8.0 to $9.0 \mathrm{AM}$. The collected plant samples were placed in plastic bags, labeled carefully and brought to the laboratory. Now the overall length of plant is measured with the help of $\mathrm{cm}$ scale.

\section{Results}

\section{Soil analysis}

It was necessary to determine the physical and chemical properties of the soil which govern both availability and relative toxicity of metal contamination such as soil $\mathrm{pH}$, moisture content and the nutritional status.

\section{pH of the soil}

$\mathrm{pH}$ of soil affects the solubility and mobility of nickel, mercury and lead. At pH below 7.0 of soil most nickel, mercury and lead ions get reduced and the solubility of these ions is greater than the salt which was initially added to the soil. The $\mathrm{pH}$ of the soil used in this study was 6.8. Therefore, this $\mathrm{pH}$ value is suitable to nickel, mercury and lead uptake by plants.

\section{Moisture content}

The moisture content of soil used in this study was $14.7 \%$.

\section{Overall growth upon lead and nickel exposure}

The growth of Dahlia (D. cardiophylla) plant on various concentrations of heavy metals was found varying (Table 1). It was observed that the dahlia plant grew well in the initial concentrations of the respective heavy metals. Significant toxicity was also tested by analysis of variance (ANOVA) test (Table 2).

\section{Discussion}

Environmental pollution through heavy metals is growing concern. The discharge of heavy metals as a byproduct of various human activities has been accompanied by large scale soil pollution. So, the contamination level in these soil were either more than normal levels, or expected to reach those levels. Research findings show that at least 20 million hectares of land, in North and South America, South Europe, Mexico and East Asia is irrigated by raw sewages. The main sources of heavy metals in soil is the use of urban and industrial waste water, fertilizers, metal extraction mines. The primary heavy metals present in sewage include Zinc, $\mathrm{Cu}, \mathrm{Pb}$, Arsenic, Nickel, Chromium and Cadmium (Table 3).

The human has expressed concern about health and environmental safety, which have resulted in scientists searching for other phytoremediation method to reduce the use of heavy metal and maintaining economic level of heavy metals because heavy metals creates many problems such as liver and kidney, gasteroenteric problems and excess nickel and other heavy metals inhibit growth and photosynthetic activity in plants and may promote aging of plants.

In recent year several plants have been used traditionally to reduce hazards heavy metals. The plant includes Tomato, spinach, ladyfinger, peppermint, brinjal, chilies, coriander, cauliflower, onion,

\begin{tabular}{|c|c|c|c|c|c|c|c|}
\hline S.No & $\mathrm{Ni}$ concentration in $\mathrm{mg} / \mathrm{kg}$ of soil & & Il leng & plant & & & Mean Growth \pm (SE) \\
\hline 1 & C & 10.3 & 11.6 & 10.8 & 9.8 & 9.7 & $10.44 \pm 0.35$ \\
\hline 2 & 0.5 & 9.6 & 9.8 & 10.3 & 9.9 & 8.2 & $9.56 \pm 0.36$ \\
\hline 3 & 1.0 & 9.7 & 8.9 & 9.9 & 7.8 & 7.8 & $8.82 \pm 0.44$ \\
\hline 4 & 1.5 & 8.7 & 7.9 & 6.6 & 8.5 & 6.2 & $7.58 \pm 0.50$ \\
\hline 5 & 2.0 & 2.6 & 2.8 & 2.24 & 3.56 & 3.76 & $2.99 \pm 0.28$ \\
\hline
\end{tabular}

Table1: Overall growth of Dahlia (Georgina wild) upon exposure to different concentrations of Nickel. C represents control.

\begin{tabular}{|l|l|l|l|}
\hline Square of variance & D.F & Sum of square & Mean of square \\
\hline Between the group & 4 & 171.21 & 42.80 \\
\hline Error & 16 & 11.9 & 0.74 \\
\hline
\end{tabular}

Table 2: Analysis of variance (ANOVA) for the overall growth of Dahlia upon exposure to different Ni concentrations. D.F represents the degree of freedom.

\begin{tabular}{|l|l|l|l|l|}
\hline Square of variance & D.F & Sum of square & Mean of square \\
\hline Between the group & 4 & 154.23 & 38.55 \\
\hline Error & 16 & 17.33 & 1.08 & 35.59 \\
\hline
\end{tabular}

Table 3: Analysis of variance (ANOVA) for the overall growth of Dahlia upon exposure to different $\mathrm{Pb}$ concentrations. D.F represents the degree of freedom.

\begin{tabular}{|l|l|l|l|l|l|l|l|}
\hline S.No & Pb concentration in $\mathbf{~ m g / k g}$ of soil & \multicolumn{3}{|c|}{ Overall length of plant } \\
\hline 1 & C & 11.7 & 9.4 & 10.4 & 12.5 & 10.9 & $10.98 \pm 0.53$ \\
\hline 2 & 5 & 10.6 & 8.5 & 8.6 & 10.7 & 9.6 & $9.6 \pm 0.47$ \\
\hline 3 & 10 & 9.7 & 7.6 & 9.7 & 7.2 & 8.9 & $8.62 \pm 0.52$ \\
\hline 4 & 15 & 8.4 & 6.6 & 6.0 & 8.1 & 6.7 & $7.16 \pm 0.46$ \\
\hline 5 & 20 & 6.4 & 4.2 & 2.4 & 2.3 & 3.3 & $3.72 \pm 0.75$ \\
\hline
\end{tabular}

Table 4: Overall growth of Dahlia upon exposure to different concentrations of Lead. C represents control. 


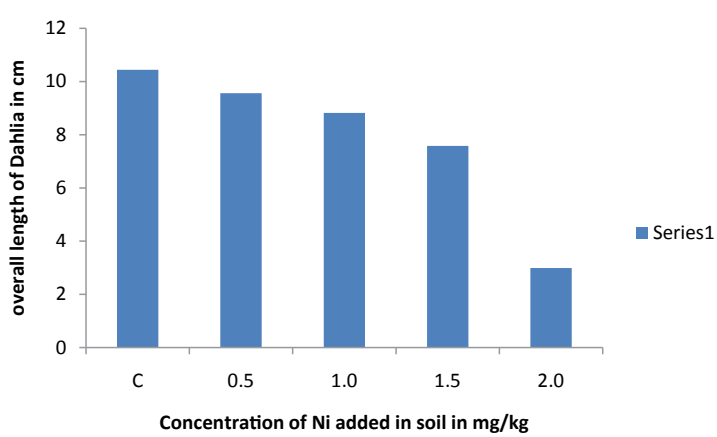

Figure 1: Showing as the concentration of metal in soil.

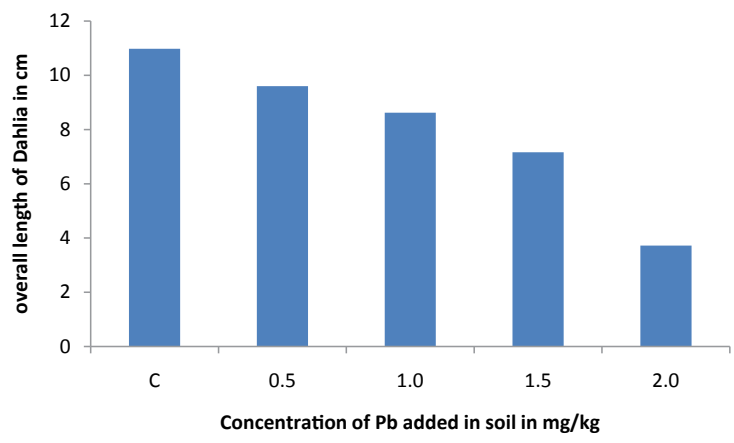

Figure 2: Showing as the concentration of metal in soil.

radish, pointedgourd, bottlegourd were analyzed by atomic absorption spectrophotometer method for determination of cadmium, chromium in these vegetables irrigated with industrial waste water around Jaipur.
In recent studies the heavy metal concentration above the normal concentration is found to inhibit the growth and accumulation ability of plant. In our study we determined the growth pattern of the dahlia on being exposed to different concentrations of heavy metal in the soil. The work was based on the recent studies that were carried out on the other plant than the Dahlia. We also determined the toxic concentration of lead and nickel which affected the growth and accumulation of lead and nickel in the plant growing in contaminated soil (Figure 1 and Figure 2). The results indicated that the high concentrations of lead and nickel affected the growth of plant (Table 4). Results showed that the root and shoot elongation decreased as the heavy metal concentration increased.

It was also observed that the shoots of the Dahlia are more tolerant than roots of dahlia plant and the biomass and seed germination also affected by the nickel and lead toxicity above the normal concentration.

\section{References}

1. Qadir MA, A Ghafoor, SL Hussain, G Murtaza, GT Mehmood (1998) Meta ion accumulation $\mathrm{m}$ vegetables and soils irrigated with city effluents. In Proceedings of 3rd National Symposium on Environmental Pollution. Held at Islamabad: 89-92.

2. Yang TX, Li MS, Li Y, Huang HR (2006) Study on heavy metal pollution in soil and plants in Pingle Manganese Mine, Guangxi and implications for ecological restoration. Mining Saf Environ Protec 1: 21-23.

3. Adamu CA, Bell PF, Mulchi C, Chaney R (1983) Residual metal concentrations in soils and leaf accumulations in tobacco a decade following farmland application of municipal sludge. Environ Pollut 56: 113-126.

4. Baker AJM, Reeves RD, Hajar ASM (1994) Heavy metal accumulation and tolerance in British populations of the metallophyte Thlaspi caerulescens $\mathrm{J}$ \& $\mathrm{C}$ Prsl (Brassicaceae). New Phytol 127: 61-68

5. Saritha K, Nanda Kumar NV (2001) Qualitative detection of selenium in fortified soil and water samples by a paper chromatographic-carboxyl esterase enzyme inhibition technique. J Chromatogr A 919: 223-228.

6. Wahla IH, Kirkham MB (2008) Heavy metal displacement in salt-water-irrigated soil during phytoremediation. Environ Pollut 155: 271-283. 